NASA/TM-2005-213570

\title{
Drag Measurements of Porous Plate Acoustic Liners
}

John D. Wolter

Glenn Research Center, Cleveland, Ohio 
Since its founding, NASA has been dedicated to the advancement of aeronautics and space science. The NASA Scientific and Technical Information (STI) Program Office plays a key part in helping NASA maintain this important role.

The NASA STI Program Office is operated by Langley Research Center, the Lead Center for NASA's scientific and technical information. The NASA STI Program Office provides access to the NASA STI Database, the largest collection of aeronautical and space science STI in the world. The Program Office is also NASA's institutional mechanism for disseminating the results of its research and development activities. These results are published by NASA in the NASA STI Report Series, which includes the following report types:

- TECHNICAL PUBLICATION. Reports of completed research or a major significant phase of research that present the results of NASA programs and include extensive data or theoretical analysis. Includes compilations of significant scientific and technical data and information deemed to be of continuing reference value. NASA's counterpart of peerreviewed formal professional papers but has less stringent limitations on manuscript length and extent of graphic presentations.

- TECHNICAL MEMORANDUM. Scientific and technical findings that are preliminary or of specialized interest, e.g., quick release reports, working papers, and bibliographies that contain minimal annotation. Does not contain extensive analysis.

- CONTRACTOR REPORT. Scientific and technical findings by NASA-sponsored contractors and grantees.
- CONFERENCE PUBLICATION. Collected papers from scientific and technical conferences, symposia, seminars, or other meetings sponsored or cosponsored by NASA.

- SPECIAL PUBLICATION. Scientific, technical, or historical information from NASA programs, projects, and missions, often concerned with subjects having substantial public interest.

- TECHNICAL TRANSLATION. Englishlanguage translations of foreign scientific and technical material pertinent to NASA's mission.

Specialized services that complement the STI Program Office's diverse offerings include creating custom thesauri, building customized databases, organizing and publishing research results ... even providing videos.

For more information about the NASA STI Program Office, see the following:

- Access the NASA STI Program Home Page at http://www.sti.nasa.gov

- E-mail your question via the Internet to help@sti.nasa.gov

- Fax your question to the NASA Access Help Desk at 301-621-0134

- Telephone the NASA Access Help Desk at 301-621-0390

- Write to:

NASA Access Help Desk

NASA Center for AeroSpace Information 7121 Standard Drive

Hanover, MD 21076 
NASA/TM-2005-213570

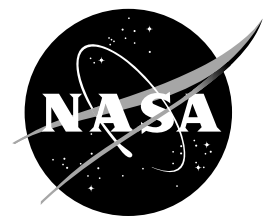

\section{Drag Measurements of Porous Plate Acoustic Liners}

John D. Wolter

Glenn Research Center, Cleveland, Ohio

Prepared for the

43rd Aerospace Sciences Meeting and Exhibit

sponsored by the American Institute of Aeronautics and Astronautics

Reno, Nevada, January 10-13, 2005

National Aeronautics and

Space Administration

Glenn Research Center 


\section{Acknowledgments}

The author would like to thank Mr. Andy Kuchar (retired), GE Aircraft Engines, for his help in the conceptualization of this experiment and Dr. Danny P. Hwang for his guidance in the development and analysis of this experiment.

Available from

NASA Center for Aerospace Information 7121 Standard Drive

Hanover, MD 21076
National Technical Information Service 5285 Port Royal Road Springfield, VA 22100

Available electronically at http:/ /gltrs.grc.nasa.gov 


\title{
Drag Measurements of Porous Plate Acoustic Liners
}

\author{
John D. Wolter \\ National Aeronautics and Space Administration \\ Glenn Research Center \\ Cleveland, Ohio 44135
}

\begin{abstract}
This paper presents the results of direct drag measurements on a variety of porous plate acoustic liners. The existing literature describes numerous studies of drag on porous walls with injection or suction, but relatively few of drag on porous plates with neither injection nor suction. Furthermore, the porosity of the porous plate in existing studies is much lower than typically used in acoustic liners. In the present work, the acoustic liners consisted of a perforated face sheet covering a bulk acoustic absorber material. Factors that were varied in the experiment were hole diameter, hole pattern, face sheet thickness, bulk material type, and size of the gap (if any) between the face sheet and the absorber material.
\end{abstract}

\section{Nomenclature}

$A \quad$ Area of liner panels

$C_{f} \quad$ Skin friction coefficient, $=($ measured force $) /\left(1 / 2 \rho_{\infty} \mathrm{u}_{\infty}{ }^{2} \mathrm{~A}\right)$

$C_{f 0} \quad$ Skin friction coefficient of nonporous plate

$d_{\text {hole }} \quad$ diameter of holes

$t \quad$ thickness of plate

$u_{\infty} \quad$ freestream velocity

$\rho_{\infty} \quad$ freestream density

\section{Introduction}

The reduction of aircraft propulsion system noise is an area of great research interest. Communities around airports demand that noise levels be reduced to their lowest practical level, and governments have responded with more stringent noise requirements. Through past research and development efforts, the aeronautics community has reduced noise levels of propulsion systems significantly. However, with regulated noise levels being continually reduced, we need to make propulsion systems of the future even quieter. One of the many approaches being used to address this need is the use of acoustic liners in the noise producing regions of aircraft engines.

While the meaning of the term "acoustic liner" varies somewhat, for our purposes, an acoustic liner is a passive noise damping surface in a flow passage. In propulsion systems, these liners are commonly used in the fan and nozzle sections of the flow path. Liners usually consist of an acoustic absorbing material covered by a perforated face sheet. The face sheet provides a relatively smooth surface over which the fluid flow may pass. The absorbing material may be divided up into small cells, but in this experiment, the material was in bulk sheets.

The existing literature contains a large number of studies of turbulent boundary layers over porous walls with injection or suction, but the number of studies without injection or suction is much smaller. These differ from the current work in two significant ways: 1. most featured significantly lower porosity than in the current work, and 2 . most were for a perforated sheet over an open cavity, such as would be used for cooling, instead of the perforated sheet over absorber material used in the current work.

Roberts $^{1}$ obtained drag measurements from pitot pressure surveys for eleven different perforated plates of various hole diameters and porosities. He correlated these measurements to an equivalent sand grain roughness for a solid plate.

Boldman and Brinich ${ }^{2}$ measured the drag on an acoustic liner panel using boundary layer momentum surveys. The liner consisted of an $8 \%$ open area perforated sheet over a honeycomb plenum. They found a $1 \%$ increase in drag relative to a smooth flat plate at $61 \mathrm{~m} / \mathrm{sec}$ and a $20 \%$ increase at $213 \mathrm{~m} / \mathrm{sec}$. They also found an increase when broadband noise sources were introduced. 
Wilkinson ${ }^{3}$ made direct drag measurements on several liner panels. The liners consisted of perforated sheets having $4.7 \%$ to $17.6 \%$ open area over honeycomb or an open plenum. He found a drag increase relative to a smooth flat plate of up to $35 \%$ at $10 \mathrm{~m} / \mathrm{sec}$ and up to $50 \%$ at $45 \mathrm{~m} / \mathrm{sec}$.

Kong, Schetz, and Collier ${ }^{4,5}$ obtained direct measurements of skin friction over smooth, roughened, and porous surfaces. Their results exhibited a 30-40\% increase in skin friction for the porous surface over a smooth flat plate at velocities of 45 to $53 \mathrm{~m} / \mathrm{sec}$. Also by examining turbulence quantities, they demonstrated that the nature of the drag increase due to porosity was different than that due to surface roughness.

\section{Apparatus}

The apparatus for this study (Figs. 1 and 2) consisted of a wind tunnel test section $12.70 \mathrm{~cm}$ high by $20.32 \mathrm{~cm}$ wide by $63.50 \mathrm{~cm}$ long. A $12.36 \mathrm{~cm}$ wide by $25.06 \mathrm{~cm}$ long opening in the lower wall of the test section allowed for the installation of various acoustic liner panel assemblies. The wind tunnel section was mounted in NASA Glenn's Advanced Nozzle Test Facility, (commonly referred to as "CE-22"). It was supplied by the facility compressed air supply and exhausted to atmospheric conditions.

The acoustic liner panel assembly was flush mounted in the opening. The assembly (Figs. 3 and 4) consisted of an aluminum frame into which were installed a support block and a bulk acoustic absorber material. A $12.36 \mathrm{~cm}$ wide by $25.06 \mathrm{~cm}$ long liner face sheet covered the filled cavity. Using shims of different thicknesses between the support block and the absorber material allowed the creation of a gap between the absorber material and the face sheet. A $0.18 \mathrm{~mm}$ gap around the edges of the frame separated the assembly from the surrounding walls.

Drag on the liner panels was measured using a single component, counterweighted swing-type force balance (Figs. 5 and 6). Although this balance includes a bellows system to
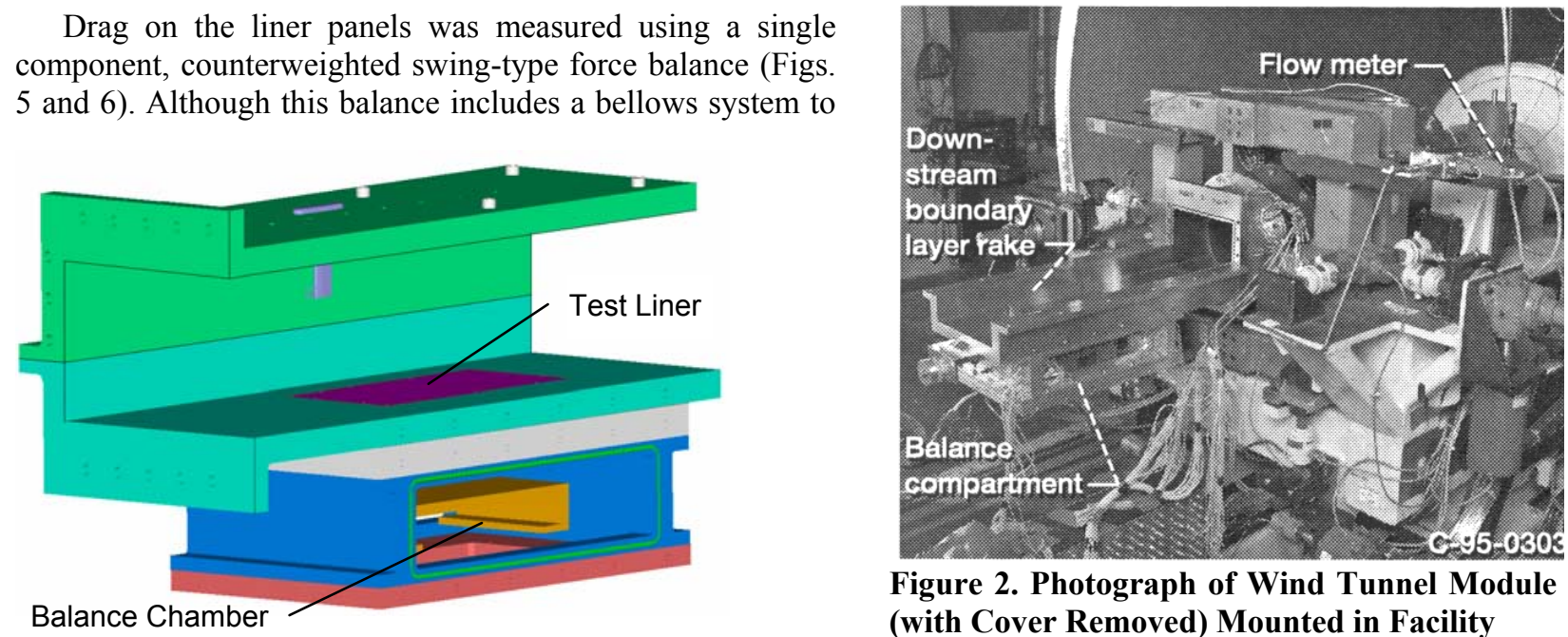

Figure 2. Photograph of Wind Tunnel Module (with Cover Removed) Mounted in Facility

Figure 1. Wind Tunnel Module

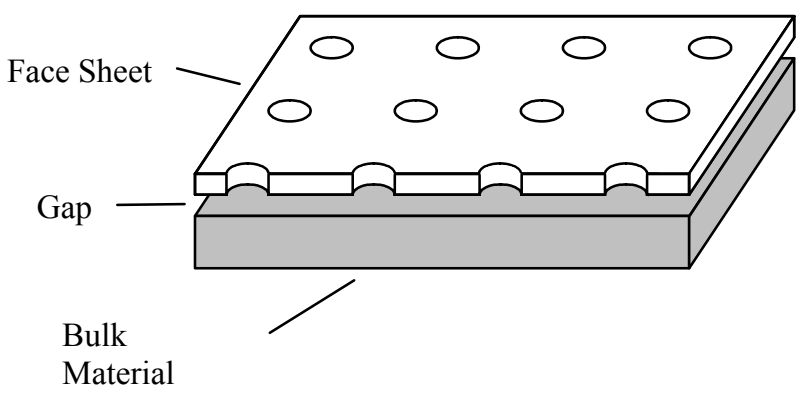

Figure 3. Perforated Plate Acoustic Liner

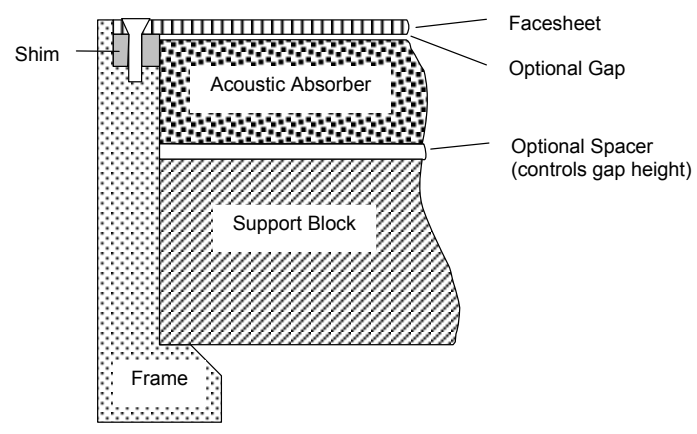

Figure 4. Cutaway View of Acoustic Liner Panel Assembly 
allow air injection through the sample, this feature was not used in the present study. Further details about the balance can be found in reference 8 . In the more recent studies, including the present study, the balance has been modified by replacing the limited variable differential transducer sensing element with a miniature loadcell and removing the magnetic fluid damper. The balance was calibrated using weights and a cable and pulley.

A 14-element pitot rake was used to measure the boundary layer at the test specimen, and in conjunction with a static pressure port at the base of the rake, to determine the freestream Mach number in the test section. The rake was mounted just downstream of the panel assembly so that the measurement would not adversely affect the flow over the panel.

The porous plate acoustic liners studied consisted of a perforated face sheet backed by a bulk acoustic absorber material. By changing the face sheet and absorber, the following parameters were varied:

Face Sheet Thickness $(t)$ - The thickness of the face sheet was varied from 0.61 to $1.067 \mathrm{~mm}(0.024$ to 0.042 inches).

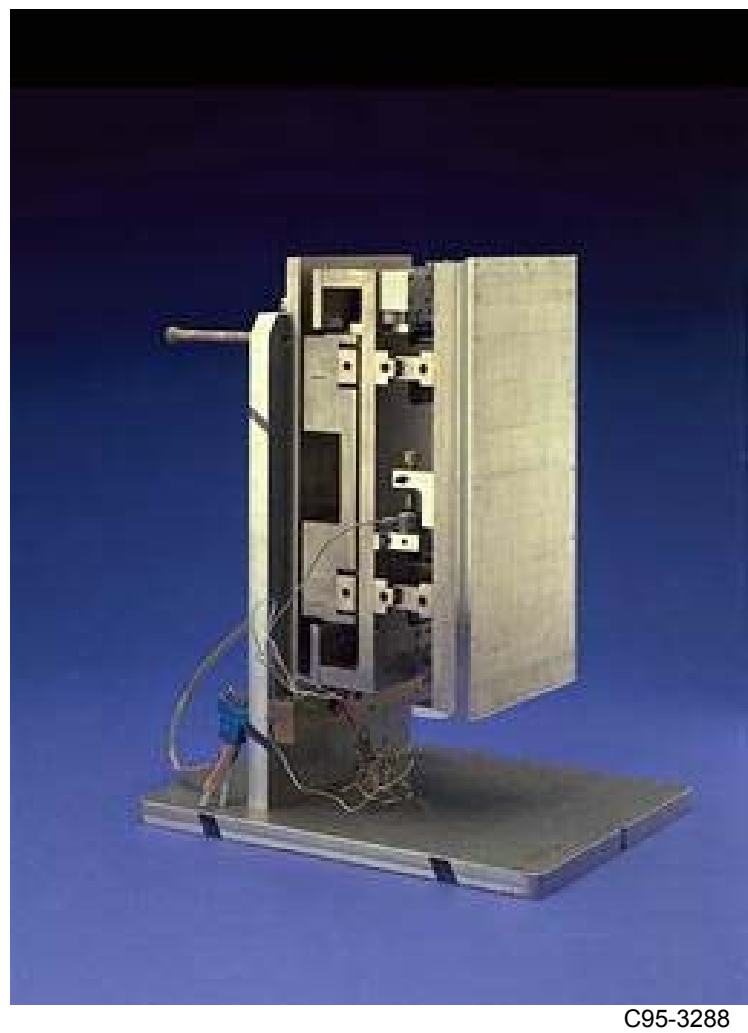

Figure 5. Photograph of Force Balance (Shown Mounted Vertically)
Face Sheet Porosity - The spacing of the holes on the face sheet was varied such that the open area of the plate ranged from $20 \%$ to $40 \%$ of the total plate area.

Hole Aspect Ratio ( $\mathrm{t} / \mathrm{dhole})$ - The ratio of face sheet thickness to hole diameter was varied from 0.4 to 1.0 .

Hole Pattern - Three arrangements of holes on the face sheet were tested (Fig. 7). The first, referred to as "inline" had holes arranged in a square pattern, with rows aligned with the flow direction. The second, "axial stagger" had a triangular pattern with rows aligned normal

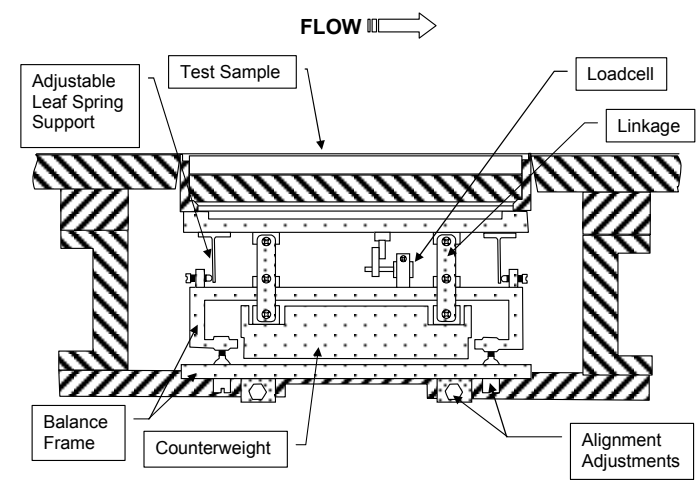

Figure 6. Cutaway View of Force Balance

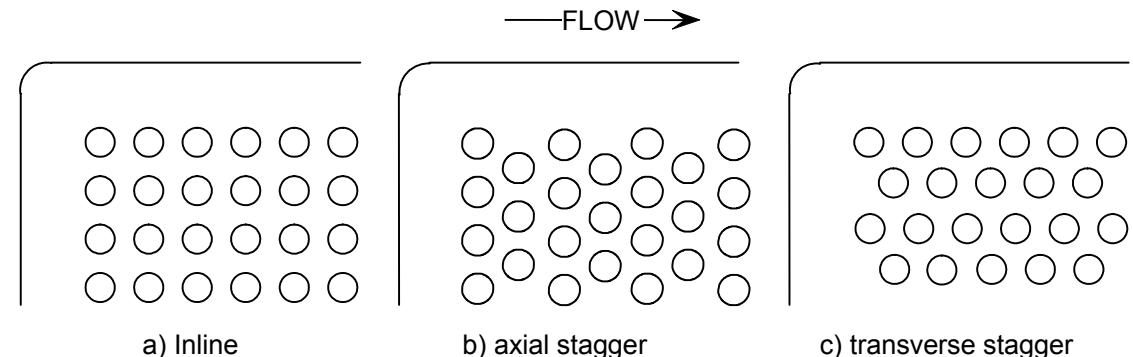

Figure 7. Face Sheet Hole Patterns 
to the flow direction. The third, referred to as "transverse stagger" had a triangular pattern with rows aligned with the flow direction.

Bulk Absorber Type - Two types of bulk absorber were used in this experiment. The first was a silicon carbide foam. The second was a composite material consisting of a ceramic fiber in an aluminum oxide matrix obtained from a sol gel process. These materials were selected for their ability to withstand the high temperatures in an exhaust system.

Face Sheet/Absorber Gap - A gap from zero to $0.25 \mathrm{~mm}$ was left between the face sheet and the bulk absorber. The purpose of this gap was to simulate erosion of the absorber material.

\section{Procedures}

Data were recorded at tunnel freestream Mach numbers of 0.3, 0.5, 0.6 and 0.7. The order of testing the various configurations was randomized as much as possible to reduce the likelihood of external factors contaminating the data. Each configuration was run at least twice to allow for the determination of measurement errors.

Table 1. Model Configurations

\begin{tabular}{|c|c|c|c|c|c|c|}
\hline $\begin{array}{l}\text { Configuration } \\
\text { ID }\end{array}$ & $\begin{array}{c}\text { Thickness, } \\
\mathrm{mm}\end{array}$ & Porosity & $\mathrm{t} / \mathrm{d}_{\text {hole }}$ & $\begin{array}{c}\text { Hole } \\
\text { Pattern }\end{array}$ & $\begin{array}{c}\text { Bulk Absorber } \\
\text { Type }\end{array}$ & $\begin{array}{c}\text { Face Sheet/ } \\
\text { Absorber Gap, mm. }\end{array}$ \\
\hline N00 & 3.43 & $0 \%$ & $\mathrm{n} / \mathrm{a}$ & none & None & $\mathrm{n} / \mathrm{a}$ \\
\hline NA1 & 1.07 & $40 \%$ & 0.4 & inline & SiC (100ppi) & 0 \\
\hline NA2 & 1.07 & $40 \%$ & 0.5 & inline & SiC (100ppi) & 0 \\
\hline NA3 & 1.07 & $40 \%$ & 0.6 & inline & SiC (100ppi) & 0 \\
\hline NA3.03 & 1.07 & $40 \%$ & 0.6 & inline & SiC (100ppi) & 0.13 \\
\hline NA3.06 & 1.07 & $40 \%$ & 0.6 & inline & SiC (100ppi) & 0.25 \\
\hline NA3.09 & 1.07 & $40 \%$ & 0.6 & inline & 1.2" composite & 0 \\
\hline NA3.12 & 1.07 & $40 \%$ & 0.6 & inline & None & 0 \\
\hline NA4 & 1.07 & $40 \%$ & 0.7 & inline & SiC (100ppi) & 0 \\
\hline NA5 & 1.07 & $40 \%$ & 0.8 & inline & SiC (100ppi) & 0 \\
\hline NA5.03 & 1.07 & $40 \%$ & 0.8 & inline & SiC (100ppi) & 0.13 \\
\hline NA5.06 & 1.07 & $40 \%$ & 0.8 & inline & SiC (100ppi) & 0.25 \\
\hline NA5.09 & 1.07 & $40 \%$ & 0.8 & inline & 1.2" composite & 0 \\
\hline NA6 & 1.07 & $40 \%$ & 1 & inline & SiC (100ppi) & 0 \\
\hline NA6.03 & 1.07 & $40 \%$ & 1 & inline & SiC (100ppi) & 0.13 \\
\hline NA6.06 & 1.07 & $40 \%$ & 1 & inline & SiC (100ppi) & 0.25 \\
\hline NA6.09 & 1.07 & $40 \%$ & 1 & inline & 1.2" composite & 0 \\
\hline NA6.10 & 1.07 & $40 \%$ & 1 & inline & None & 0 \\
\hline NA6.11 & 1.07 & $40 \%$ & 1 & inline & 0.5 " composite & 0 \\
\hline NA6.12 & 1.07 & $40 \%$ & 1 & inline & 0.5 " composite & 0.13 \\
\hline NA6.13 & 1.07 & $40 \%$ & 1 & inline & 0.5 " composite & 0.25 \\
\hline NB1 & 1.07 & $40 \%$ & 0.4 & axial & SiC (100ppi) & 0 \\
\hline NB2 & 1.07 & $40 \%$ & 0.5 & axial & SiC (100ppi) & 0 \\
\hline NB3 & 1.07 & $40 \%$ & 0.6 & axial & SiC (100ppi) & 0 \\
\hline NB4 & 1.07 & $40 \%$ & 0.7 & axial & SiC (100ppi) & 0 \\
\hline NB5 & 1.07 & $40 \%$ & 0.8 & axial & SiC (100ppi) & 0 \\
\hline NB6 & 1.07 & $40 \%$ & 1 & axial & SiC (100ppi) & 0 \\
\hline NB6A & 1.07 & $40 \%$ & 1 & axial & SiC (100ppi) & 0 \\
\hline NB7 & 1.02 & $40 \%$ & 0.74 & axial & SiC (100ppi) & 0 \\
\hline NB8 & 1.02 & $40 \%$ & 0.74 & transverse & SiC (100ppi) & 0 \\
\hline NC1 & 1.07 & $30 \%$ & 0.6 & inline & SiC (100ppi) & 0 \\
\hline NC2 & 1.07 & $30 \%$ & 0.8 & inline & SiC (100ppi) & 0 \\
\hline NC3 & 1.07 & $30 \%$ & 1 & inline & SiC (100ppi) & 0 \\
\hline ND1 & 1.07 & $20 \%$ & 0.6 & inline & SiC (100ppi) & 0 \\
\hline
\end{tabular}




\begin{tabular}{|l|c|c|c|c|c|c|}
\hline $\begin{array}{l}\text { Configuration } \\
\text { ID }\end{array}$ & $\begin{array}{c}\text { Thickness, } \\
\mathrm{mm}\end{array}$ & Porosity & $\mathrm{t} / \mathrm{d}_{\text {hole }}$ & $\begin{array}{c}\text { Hole } \\
\text { Pattern }\end{array}$ & $\begin{array}{c}\text { Bulk Absorber } \\
\text { Type }\end{array}$ & $\begin{array}{c}\text { Face Sheet/ } \\
\text { Absorber Gap, } \mathrm{mm} .\end{array}$ \\
\hline ND2 & 1.07 & $20 \%$ & 0.8 & inline & $\mathrm{SiC}(100 \mathrm{ppi})$ & 0 \\
\hline ND3 & 1.07 & $20 \%$ & 1 & inline & $\mathrm{SiC}(100 \mathrm{ppi})$ & 0 \\
\hline NE2 & 0.61 & $40 \%$ & 0.5 & inline & $\mathrm{SiC}(100 \mathrm{ppi})$ & 0 \\
\hline NE2B & 0.61 & $40 \%$ & 0.5 & inline & SiC (100ppi) & 0 \\
\hline PN23 & 1.02 & $23 \%$ & 6.2 & axial & SiC (100ppi) & 0 \\
\hline
\end{tabular}

For each test condition a skin friction coefficient was calculated based on the measured thrust and freestream conditions. This coefficient was normalized by the skin friction drag coefficient of a non-porous flat plate to form the skin friction ratio.

\section{Results and Discussion}

Fig. 8 shows results for the three different porosities over a range of hole aspect ratios. The data shown are for the inline hole pattern, $\mathrm{SiC}$ absorber with no face sheet absorber gap. As can be seen, porosity affects not only in the drag, but also the shape of the skin friction ratio vs. hole aspect ratio curve. Thickness to hole diameter ratio also appears to have a significant impact, although the trends for these two parameters combined are not entirely consistent. Presentation of figures in the following paragraphs was restricted to the $40 \%$ porosity configurations of greatest interest.

Fig. 9 shows the effect of hole aspect ratio on friction ratio. Data is shown for freestream Mach number of 0.6 , although data for other Mach numbers is similar. The figure suggests that there might be a slight decrease in friction ratio as hole aspect ratio increases, but results of a linear regression failed to find a statistically significant relationship. This result is somewhat surprising, as Hwang ${ }^{9}$ and others have found a significant relationship between hole aspect ratio and friction ratio.

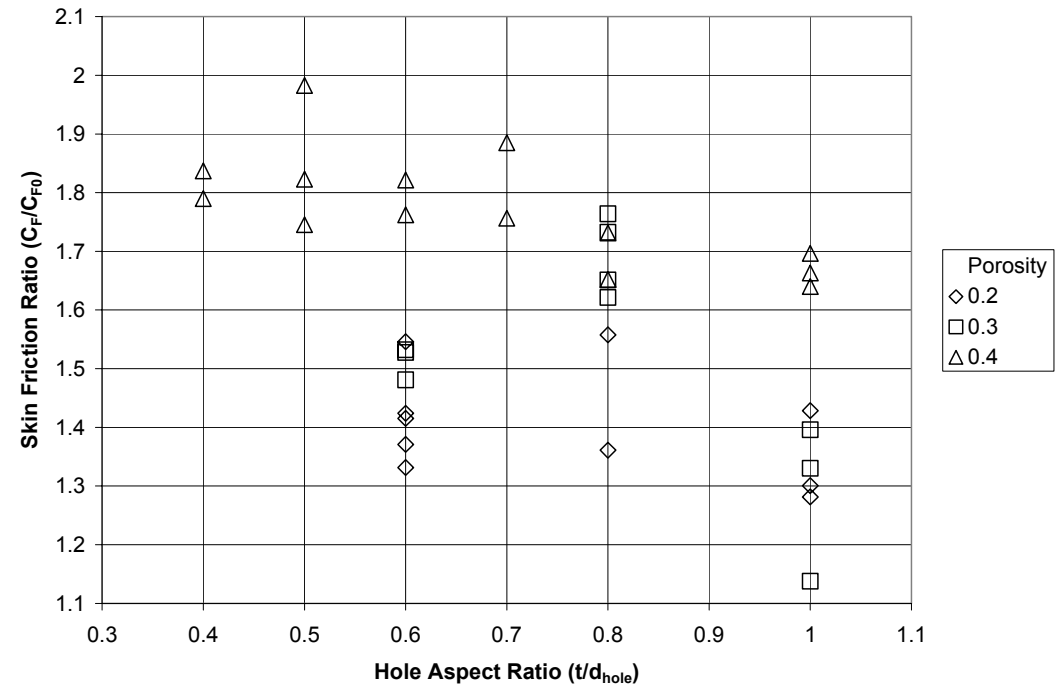

Figure 8. Effects of Porosity and Hole Aspect Ratio on Friction Ratio
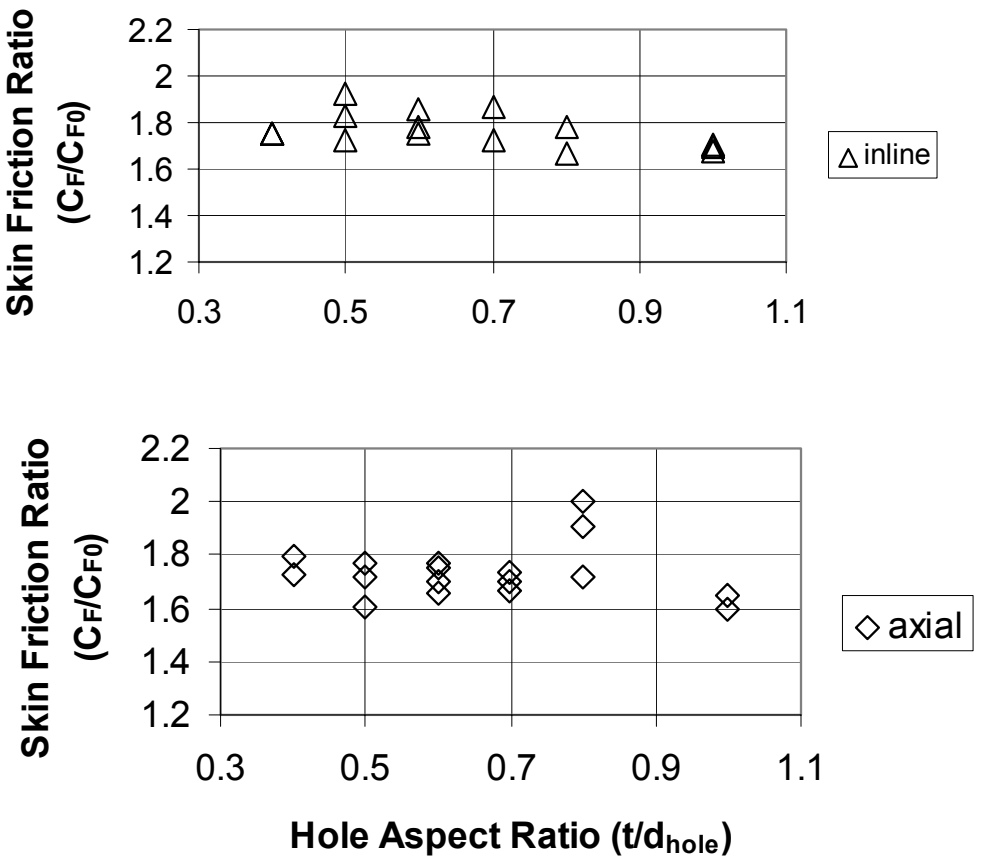

Figure 9. Effect of Hole Aspect Ratio (40\% porositv) 
Fig. 10 shows the effect of hole stagger on friction ratio. From the plot, it can be observed that there is a small increase in friction for the inline hole pattern versus the staggered. The analysis reveals that this difference is statistically significant. However, no significant difference was observed for different orientations of the stagger pattern. This result was unexpected, as the mechanism for drag due to hole stagger was expected to be related to a wake from an upstream hole interacting with a downstream hole. Clearly such a mechanism would not account for this result.

Fig. 11 shows the effect of gap height on friction ratio. The figures suggest that there might be an effect, but results of a linear regression indicate that the trends are not statistically significant. This result does not, of course, rule out a nonlinear effect. This result suggests that migration of flow behind the liner face sheet was not a significant contributor to liner drag.

Fig. 12 shows the effect of bulk material type on friction ratio. Bulk material type had no observed effect on the drag of the plates. This result is not surprising, as the bulk material is not exposed to airflow of significant velocity.

Accurate measurement of applied force is one of the deceptive aspects of experimental work. It appears to be simple and straightforward, but rarely is. There are so many factors which can adversely influence a force measurement. After the conclusion of this experiment, it was discovered that the force system used herein was quite sensitive to pressure gradients in the flow direction. A ramp shaped insert was attached to the wall of the tunnel opposite the force element, to create a pressure gradient in the flow. It was found that the force balance reacted to the pressure gradient, due to the pressure forces on the forward- and aft-facing surfaces of the frame to which the liner panels were mounted. While this induced pressure gradient was not present in this experiment, a much smaller gradient is to be expected due to the
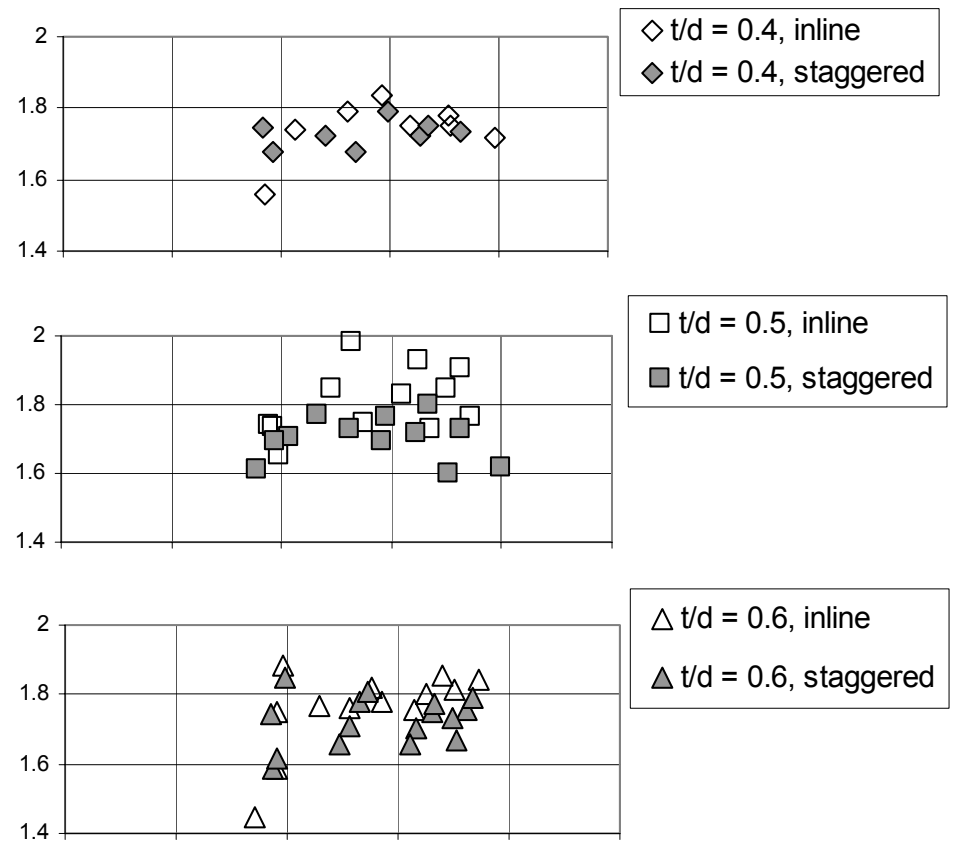

$\Delta t / d=0.6$, inline

$\Delta \mathrm{t} / \mathrm{d}=0.6$, staggered

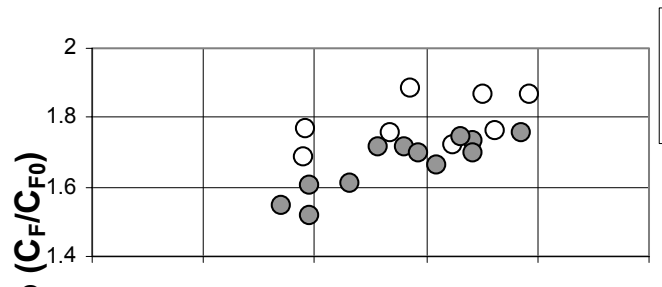

$O \mathrm{t} / \mathrm{d}=0.7$, inline

$\mathrm{O} \mathrm{t} / \mathrm{d}=0.7$, staggered

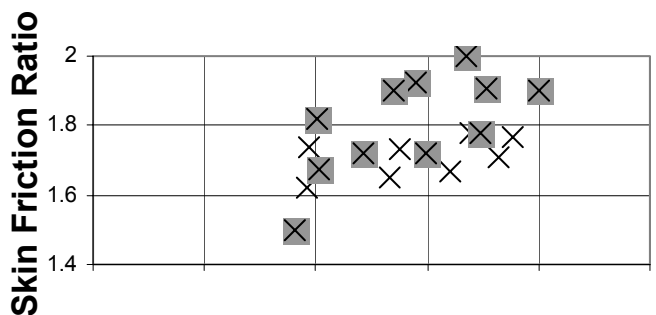

$\times \mathrm{t} / \mathrm{d}=0.8$, inline

$X \mathrm{t} / \mathrm{d}=0.8$, staggered

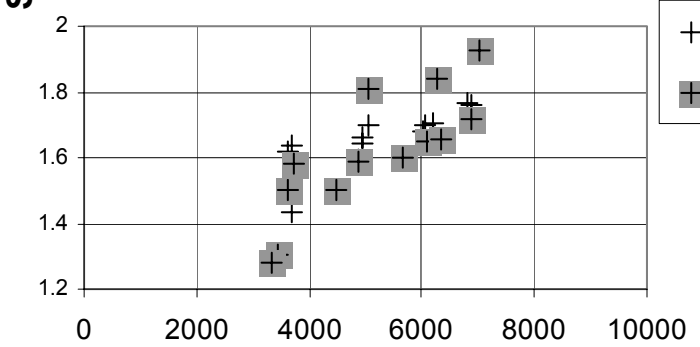

Reynolds Number Based on Momentum Thickness

Figure 10. Effect of Stagger on Friction Ratio (40\% Porosity) 
development of the boundary layer along the plate. The results from this experiment have not been corrected for this effect, as the pressures acting on the frame were not measured. The results in figs. 11 and 12 suggest that this effect should be small. It is still believed that the results of this experiment, particularly trends between results, are valid, but numerical values should be used with caution.

The force balance did not perform as well as desired during this test program. Consequently there was considerable scatter in the measured data. Using the large number of repeated measurements, the accuracy of individual measurements was assessed. This analysis showed an accuracy of the friction ratio of \pm 0.135 at a confidence level of $95 \%$.

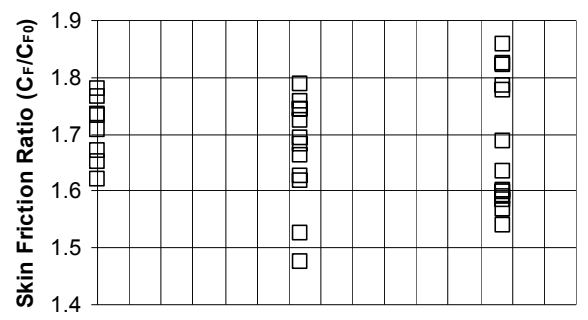

$\square \mathrm{t} / \mathrm{d}=0.8$

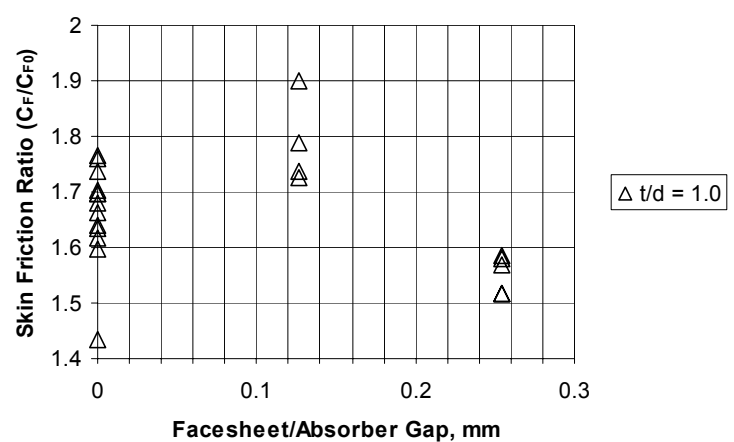

\section{Figure 11. Effect of Face Sheet/Absorber Gap on Friction Ratio (40\% Porosity)}

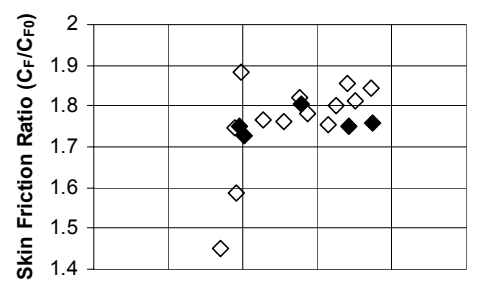

$\diamond 0.5^{\prime \prime} \mathrm{SiC}, \mathrm{t} / \mathrm{d}=0.6$

$\bullet 1.2^{\prime \prime} \mathrm{TF}, \mathrm{t} / \mathrm{d}=0.6$

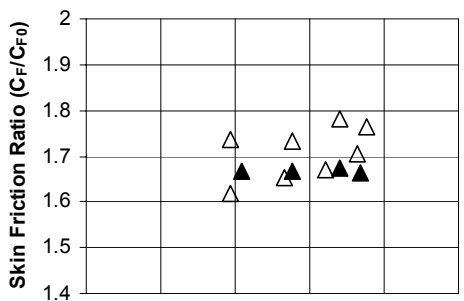

$\Delta 0$. " $^{\mathrm{I}} \mathrm{SiC}, \mathrm{t} / \mathrm{d}=0.8$

$\Delta 1.2^{\prime \prime} \mathrm{TF}, \mathrm{t} / \mathrm{d}=0.8$

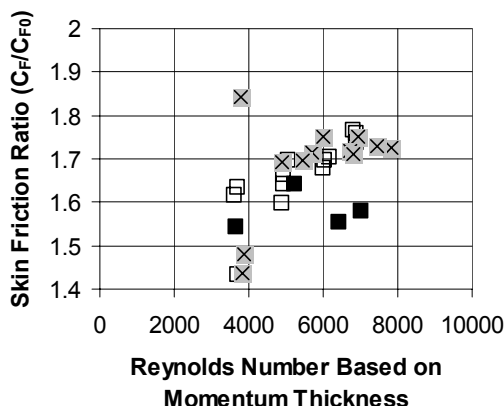

$\square 0.5^{\prime \prime} \mathrm{SiC}, \mathrm{t} / \mathrm{d}=1.0$

- 1.2" TF, $\mathrm{t} / \mathrm{d}=1.0$

$\times 0.5^{\prime \prime} \mathrm{TF}, \mathrm{t} / \mathrm{d}=1.0$

Figure 12. Effect of Absorber Material on Friction Ratio (40\% Porosity)

\section{Summary and Conclusions}

Direct drag measurements were made on a series of perforated plate acoustic liners. Face sheet thickness, porosity, hole pattern, and hole aspect ratio as well as bulk absorber type and face sheet/absorber gap were varied. Face sheet porosity had a significant impact on drag ratio. For the $40 \%$ porosity configurations, hole pattern was found to have a significant effect on drag ratio. Factors relating to the geometry within and behind the face sheet, such as hole aspect ratio, bulk absorber type, and face sheet/absorber gap did not have significant effect on the drag ratio. These findings suggest that migration of flow behind the face sheet did not have a significant impact on drag in this experiment. 


\section{References}

${ }^{1}$ Roberts, D. W. "Equivalent Sand-Grain Roughness of Perforated Plate Acoustic Linings,” AIAA Paper 77-104, January, 1977.

${ }^{2}$ Boldman, D. R. and Brinich, P. F. "Skin Friction on a Flat Perforated Acoustic Liner," AIAA Journal, vol. 14, page 197, November, 1976.

${ }^{3}$ Wilkinson, S.P. “Influence Of Wall Permeability on Turbulent Boundary Layer Properties," AIAA Paper 83-0294, January, 1983.

${ }^{4}$ Kong, F. Y. and Schetz, J. A. "Turbulent Boundary Layer Over Porous Surfaces with Different Surface Geometries,” AIAA Paper 82-0030 January, 1982.

${ }^{5}$ Kong, F. Y., Schetz, J. A., and Collier, F. "Turbulent Boundary Layer Over Solid And Porous Surfaces With Small Roughness," NASA-CR-168990, March, 1982.

${ }^{6}$ Beltran, L.R., Delroso, R.L., Delrosario, R. “Advanced Nozzle and Engine Components Test Facility,” NASA TM 103684, January 1992.

${ }^{7}$ Kerl, J.M., Severt, G.A., Loos, K.H. “Advanced Nozzle Test Facility at NASA Glenn Research Center,” AIAA Paper 2002-3245, June, 2002.

${ }^{8}$ Voisinet, R.L.P. "Influence of Roughness and Blowing on Compressible Turbulent Boundary Layer Flow," NSWC TR 79153, June, 1979.

${ }^{9}$ Hwang, D.P. "Experimental Study of Characteristics of Micro-Hole Porous Skins for Turbulent Skin Friction Reduction," ICAS 2002 Congress, September, 2002. 


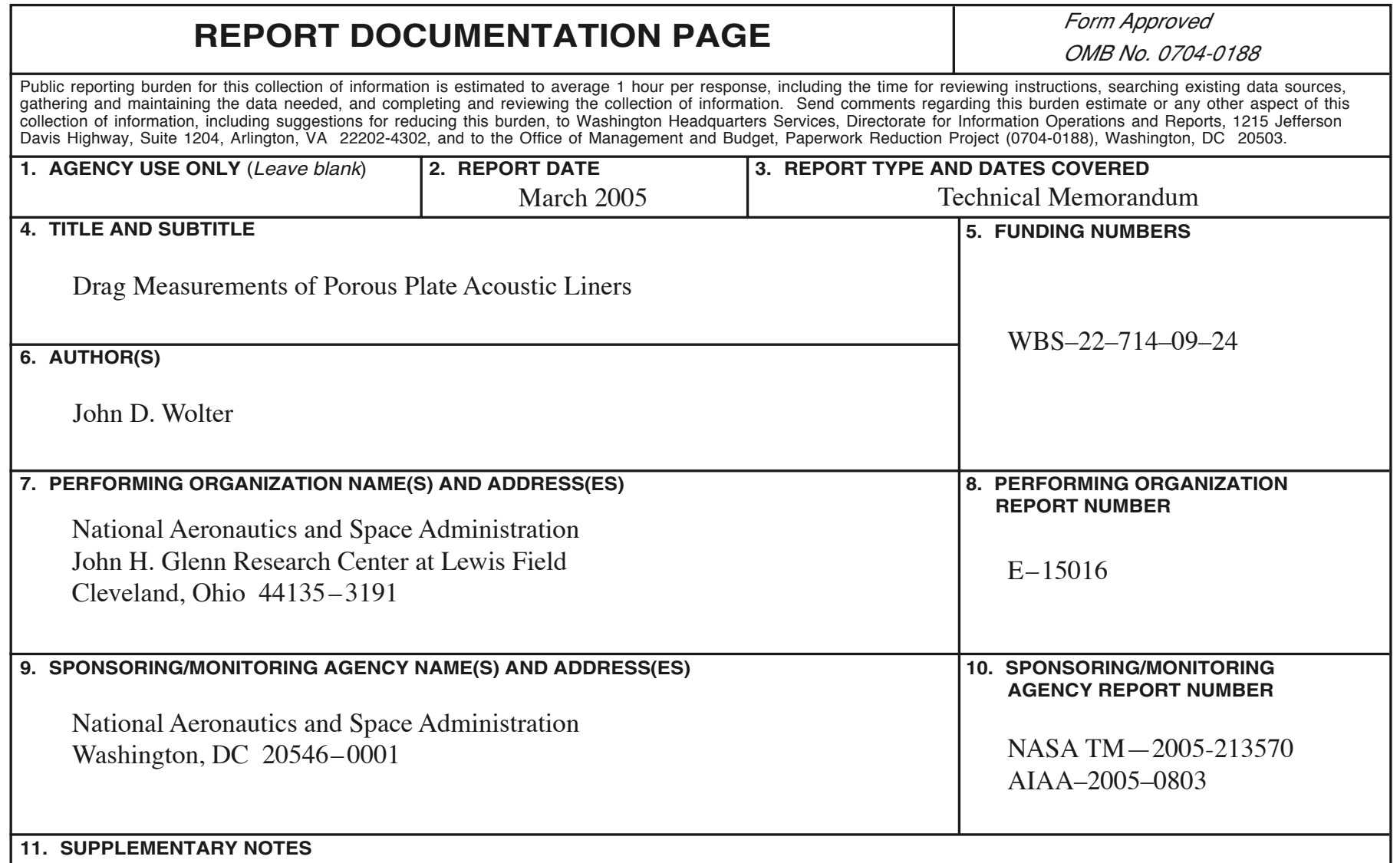

Prepared for the 43rd Aerospace Sciences Meeting and Exhibit sponsored by the American Institute of Aeronautics and Astronautics, Reno, Nevada, January 10-13, 2005. Responsible person, John D. Wolter, organization code RTN, 216-433-3941.

\begin{tabular}{l|l}
\hline 12a. DISTRIBUTION/AVAILABILITY STATEMENT & 12b. DISTRIBUTION CODE \\
Unclassified - Unlimited & \\
Subject Category: 02 & \\
Available electronically at http://gltrs.grc.nasa.gov & \\
This publication is available from the NASA Center for AeroSpace Information, 301-621-0390. &
\end{tabular}

\section{ABSTRACT (Maximum 200 words)}

This paper presents the results of direct drag measurements on a variety of porous plate acoustic liners. The existing literature describes numerous studies of drag on porous walls with injection or suction, but relatively few of drag on porous plates with neither injection nor suction. Furthermore, the porosity of the porous plate in existing studies is much lower than typically used in acoustic liners. In the present work, the acoustic liners consisted of a perforated face sheet covering a bulk acoustic absorber material. Factors that were varied in the experiment were hole diameter, hole pattern, face sheet thickness, bulk material type, and size of the gap (if any) between the face sheet and the absorber material.

\begin{tabular}{|c|c|c|}
\hline \multicolumn{3}{|l|}{ 14. SUBJECT TERMS } \\
\hline \multicolumn{3}{|c|}{$\begin{array}{l}\text { Wind tunnel tests; Flat plates; Aerodynamic drag; Hole geometry (mechanics); Skin } \\
\text { friction; Linings; Friction; Porous plates; Drag; Porosity }\end{array}$} \\
\hline $\begin{array}{l}\text { 17. SECURITY CLASSIFICATION } \\
\text { OF REPORT }\end{array}$ & $\begin{array}{l}\text { 18. SECURITY CLASSIFICATION } \\
\text { OF THIS PAGE }\end{array}$ & $\begin{array}{l}\text { 19. SECURITY CLASSIFICATION } \\
\text { OF ABSTRACT }\end{array}$ \\
\hline Unclassified & Unclassified & Unclassified \\
\hline
\end{tabular}



